\title{
NITROGEN AND SULPHUR IN MARANDU GRASS: RELATIONSHIP BETWEEN SUPPLYAND CONCENTRATION IN LEAF TISSUES
}

\author{
Karina Batista ${ }^{1}$; Francisco Antonio Monteiro* \\ ${ }^{l}$ USP/ESALQ - Programa de Pós-Graduação em Solos e Nutrição de Plantas. \\ ${ }^{2}$ USP/ESALQ - Depto. Ciência do Solo, C. P. 9 - 13418-900 - Piracicaba, SP - Brasil. \\ *Corresponding author <famontei@esalq.usp.br>
}

\begin{abstract}
In order to better assess the nutritional status of forage grasses there has been an increasing interest in studying the nutrient concentrations present in different parts of plant shoot. The aim of this work was to evaluate the nitrogen and sulphur concentrations in leaf tissues of Brachiaria brizantha cv. Marandu grown in nutrient solutions with combined rates of both nitrogen and sulphur. An experiment was conducted in a greenhouse during the Spring season in PiracicabaSP, Brazil, using ground quartz as substrate. A fractionated $5^{2}$ factorial design was used, with 13 combinations of nitrogen and sulphur rates in the solutions, in $\mathrm{mg} \mathrm{L}^{-1}$, as follows: 14 and $3.2 ; 14$ and 32; 14 and $80 ; 126$ and $12.8 ; 126$ and $64 ; 210$ and $3.2 ; 210$ and $32 ; 210$ and $80 ; 336$ and $12.8 ; 336$ and $64 ; 462$ and 3.2; 462 and 32, and 462 and 80. The experimental units were set in a randomized block design, with four replications. Plants were harvested twice. Emerging leaves, recently expanded lamina and mature lamina were sampled separately at each harvest time. In these three types of tissues the nitrogen concentration was closely related to the nitrogen supply in the solution, whereas the sulphur concentration, N:S ratio and chlorophyll meter (SPAD) readings depended upon the supply of both nitrogen and sulphur. Mature lamina did not relate well to the changing in sulphur supply. To properly assess the nitrogen and sulphur concentrations, N:S ratio and SPAD readings for the Marandu grass, the two recently expanded lamina were the best tissues to indicate the availability of both nitrogen and sulphur in the nutrient solution.
\end{abstract}

Key words: Brachiaria brizantha, nitrogen concentration, sulphur concentration, N:S ratio, leaf diagnosis

\section{NITROGÊNIO E ENXOFRE NO CAPIM-MARANDU: RELAÇÃO ENTRE SUPRIMENTO E CONCENTRAÇÃO NOS TECIDOS FOLIARES}

\begin{abstract}
RESUMO: Há clara demanda de conhecimento da concentração de nutrientes nos componentes da parte aérea das plantas para subsidiar a avaliação do estado nutricional das gramíneas forrageiras. Para contribuir nessa área, objetivou-se avaliar as concentrações de nitrogênio e enxofre em tecidos foliares da Brachiaria brizantha cv. Marandu, cultivada em solução nutritiva com doses combinadas de nitrogênio e de enxofre. Foi conduzido um experimento em casa de vegetação no período da primavera, em Piracicaba-SP, empregando sílica como substrato. Utilizou-se um esquema fatorial $5^{2}$ fracionado, com 13 combinações das doses de nitrogênio e enxofre na solução, em $\mathrm{mg} \mathrm{L}^{-1}$ : 14 e 3,2; 14 e $32 ; 14$ e $80 ; 126$ e 12,$8 ; 126$ e $64 ; 210$ e 3,$2 ; 210$ e $32 ; 210$ e $80 ; 336$ e 12,$8 ; 336$ e $64 ; 462$ e 3,$2 ; 462$ e 32 e 462 e 80 . As unidades experimentais foram distribuídas segundo o delineamento de blocos ao acaso, com quatro repetições. Foram realizados dois cortes nas plantas e, em cada um, foram amostradas as folhas emergentes, as lâminas de folhas recém-expandidas e as lâminas de folhas maduras. Nos três tipos de tecidos amostrados, a concentração de nitrogênio foi estritamente relacionada ao suprimento de nitrogênio, enquanto a concentração de enxofre, a relação N:S e o valor SPAD dependeram do fornecimento tanto de nitrogênio como de enxofre. As lâminas de folhas maduras não refletiram a variação no suprimento de enxofre. Na avaliação das concentrações de nitrogênio e de enxofre, da relação N:S e do valor SPAD no capim-Marandu as lâminas de folhas recém-expandidas foram as melhores indicadoras da disponibilidade de nitrogênio e enxofre no meio de crescimento.

Palavras-chave: Brachiaria brizantha, concentração de nitrogênio, concentração de enxofre, relação $\mathrm{N}: \mathrm{S}$, diagnose foliar
\end{abstract}




\section{INTRODUCTION}

Low nutrient availability in pasture soils is one of the greatest constraints for forage productivity and quality. Nitrogen is the main limiting nutrient in established swards. Sulphur, which has lower plant demand than nitrogen, has been neglected in Brazilian pasture fertilization. Nitrogen deficient forages do not respond to sulphur supply (Jones, 1963). Millard et al. (1985) stated that the ratio between the nitrogen and sulphur applied as fertilizer is a key point for determining sulphur needs and Lolium perenne response to sulphur application. Also, pastures fertilized with high nitrogen rates require greater sulphur supply (Werner \& Monteiro, 1988).

Nutrient concentration in plant tissues has been used as the main tool for nutritional diagnosis. However, the use of the ratio between nitrogen and sulphur is recommended in addition to their respective elemental concentrations (Dijkshoorn \& Lampe, 1960; Marschner, 1995). Furthermore, chlorophyll meter readings (SPAD) are used to evaluate the nitrogen nutrition of some species, as apple (Nielsen et al., 1995), corn (Dwyer et al., 1991), and sorghum and pigeon pea (Yamamoto et al., 2002), but information is scarce for forage grasses (Colozza, 1998).

Traditionally whole plant shoots are sampled for forage nutritional diagnosis (Stevens, 1985; Monteiro, 2004; Hitsuda et al., 2005), however, attempts have been made in collecting and analyzing parts of the forage plant tops. (Werner \& Haag, 1972; Meirelles et al., 1988; Mattos, 1997; Santos, 1997; Manarin, 2000; Pereira, 2001; Gislum et al., 2003; Cherney et al., 2004).

The objective of the present study was to determine the concentrations of nitrogen and sulphur and the $\mathrm{N}: \mathrm{S}$ ratios in three plant shoot parts, as well as SPAD values in the newly expanded leaves, as a function of nitrogen and sulphur supply for the Marandu grass.

\section{MATERIAL AND METHODS}

A greenhouse experiment was conducted during the Spring season at Piracicaba, State of São Paulo, Brazil $\left(22^{\circ} 42^{\prime} \mathrm{S} ; 4^{\circ} 38^{\prime} \mathrm{W}\right)$ with the forage grass Brachiaria brizantha Marandu cultivar, grown in 3.6 $\mathrm{L}$ plastic pots filled with ground quartz.

Combinations of nitrogen and sulphur rates were tested in nutrient solutions. Five nitrogen rates (14; 126; 210; 336 and $\left.462 \mathrm{mg} \mathrm{L}^{-1}\right)$ and five sulphur rates $\left(3.2 ; 12.8 ; 32 ; 64\right.$ and $\left.80 \mathrm{mg} \mathrm{L}^{-1}\right)$ were combined in a fractionated $5^{2}$ factorial based on Littell \& Mott (1975), and the resulting 13 combinations were: 14 /
$3.2 ; 14 / 32 ; 14 / 80 ; 126 / 12.8 ; 126 / 64 ; 210 / 3.2 ; 210 / 32$; $210 / 80 ; 336 / 12.8 ; 336.64 ; 462 / 3.2 ; 462 / 32$ and $462 /$ $80 \mathrm{mg} \mathrm{L}^{-1}$. All nutrient solutions were prepared by modifying the Sarruge (1975) complete solution. The experiment was set in a randomized block design, with four replications.

Plants were harvested twice. The first harvest occurred 39 days after seedlings transplant to pots while the second occurred 40 days after the first. At each harvest, three leaf tissues were collected from plant shoots: a) emergent leaves (EL, leaves not fully expanded); b) newly expanded lamina leaf (NL, lamina of the two most recently expanded leaves); mature leaf lamina (ML, lamina of all other expanded leaves). Plant material was dried to a constant weight in an air-circulating oven set at $70^{\circ} \mathrm{C}$. Dried samples were ground in a Willey mill and stored in plastic bags prior to laboratory analysis. Nitrogen (micro Kjeldahl method) and sulphur (turbidimetric method) concentrations were determined according to the methodology presented by Sarruge \& Haag (1974).

The SPAD value was determined using the Chlorophyll Meter SPAD-502 (Soil-Plant Analysis Development, Minolta, 1989). This value was obtained non-destructively on the +2 fully expanded leaf (second expanded leaf from the top of the shoot). Determinations were made in the first plant growth period, when five readings were taken on plants from each pot with the apparatus sensor at the one-third portion in the middle of the lamina, taking care to avoid the midrib.

Data were analyzed through the Statistical Analysis System (SAS Institute, 1996), starting with the ANOVA. Response surface methodology was applied using the Response Surface Regression (RSREG) procedure when the nitrogen $\mathrm{x}$ sulphur interaction was significant. For data without significance for this interaction, the General Linear Model (GLM) procedure was used for the first and second degree regression analysis. The significance level for all statistical analysis was $5 \%$.

\section{RESULTS AND DISCUSSION}

\section{Nitrogen in leaf tissues}

The interaction between nitrogen and sulphur rates applied to Marandu grass was not significant for the nitrogen concentration in emergent leaves, newly expanded leaf lamina and mature leaf lamina sampled at the first harvest. However, nitrogen rates affect the nitrogen concentrations in all three types of leaf tissues (Figure 1). This nutrient concentration was increased by 2.1 to 2.6 fold when the nitrogen supply changed from 14 to $462 \mathrm{mg} \mathrm{L}^{-1}$ in solution. 
At any nitrogen rate, the nitrogen concentration in emergent leaves and newly expanded leaf lamina was higher than in mature leaf lamina (Figure 1). Plants transfer nitrogen to younger tissues, which import higher amounts of nutrients than they export prior to reaching maturity (Marschner, 1995).
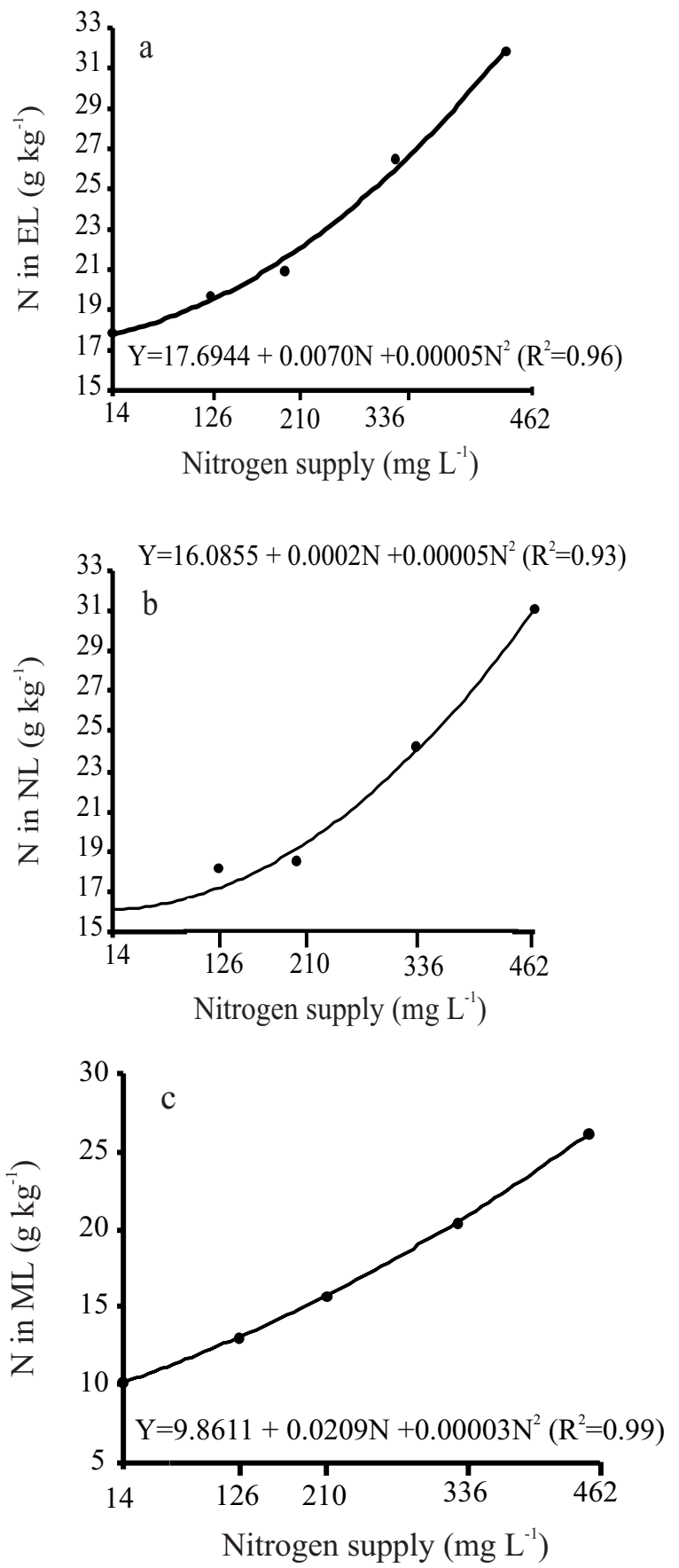

Figure 1 - (a) Nitrogen concentration in emergent leaves (EL), (b) in newly expanded leaf lamina (NL), and (c) in mature leaf lamina (ML) collected at the first harvest of Marandu grass, as related to the nitrogen rates in nutrient solution.
Both the increase in nitrogen concentrations in all three types of leaf tissues and the highest concentration of this nutrient being in the youngest leaves may contribute to cattle nutrition in grazed pastures fertilized with nitrogen as a consequence of the animal preference for leaves in the shoot.

For the nitrogen concentration in those tissues sampled at the second harvest of Marandu grass, the interaction between nitrogen and sulphur was only significant for the emergent leaves. Otherwise the concentration of this nutrient was increased by nitrogen rates (Figure 2). On the other hand, nitrogen concentration in mature leaf lamina did not change significantly at this sampling time.

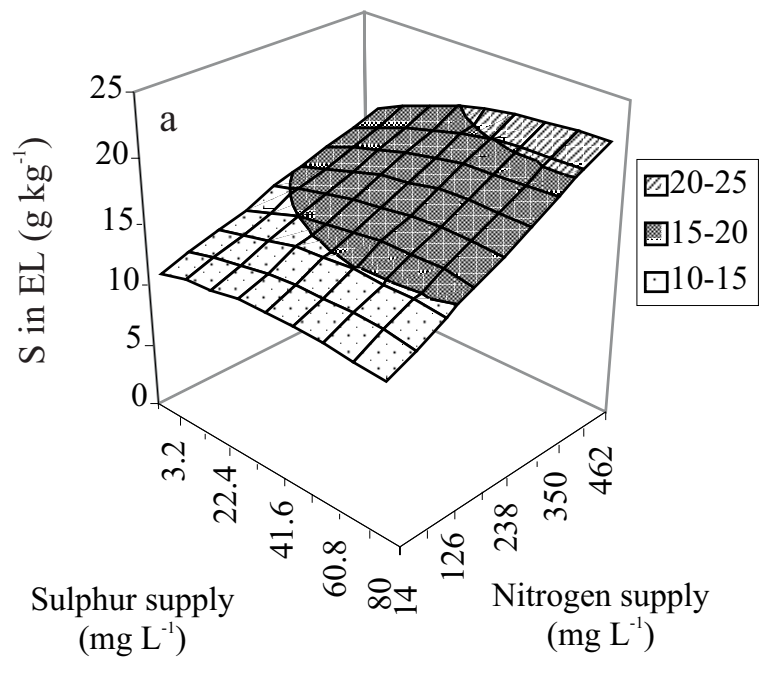

$\mathrm{Y}=11.0920+0.0129 \mathrm{~N}+0.0000003 \mathrm{~N}^{2}+$ $0.0623 \mathrm{~S}-0.0007 \mathrm{~S}^{2}+0.0001 \mathrm{NS}\left(\mathrm{R}^{2}=0.80\right)$

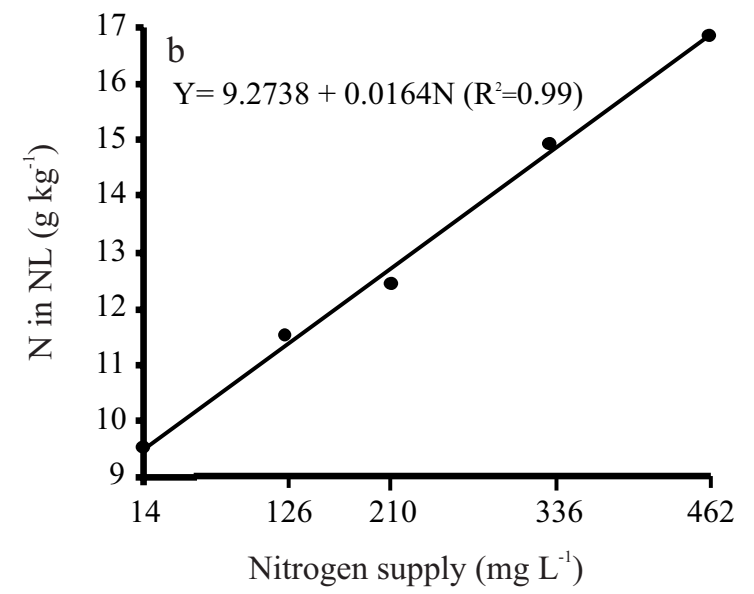

Figure 2 - (a) Nitrogen concentration in emergent leaves (EL) as related to the nitrogen and sulphur rates combinations, and (b) in newly expanded leaf lamina (NL) in relation to the nitrogen rates, at the second harvest of Marandu grass. 
The greatest nitrogen concentrations (about 20 to $22 \mathrm{~g} \mathrm{~kg}^{-1}$ ) in emergent leaves sampled at the second harvest were found for the highest nitrogen rates (more than $400 \mathrm{mg} \mathrm{L}^{-1}$ ) combined with sulphur at least in the intermediate rates (more than $40 \mathrm{mg} \mathrm{L}^{-1}$ ) (Figure 2a). This need of sulphur supply together with nitrogen was explained by Stevens (1985) through the requirement of an adequate ratio in the supply of both nutrients in order to prevent imbalance in their ratio in plant proteins.

Nitrogen concentration range in the newly expanded leaf lamina was lower at the second sampling time (9.3 to $\left.16.9 \mathrm{~g} \mathrm{~kg}^{-1}\right)$ than at the first one (16.1 to $\left.31.0 \mathrm{~g} \mathrm{~kg}^{-1}\right)$. However, in this leaf tissue collected at the second harvest nitrogen concentration linearly increased as the nitrogen supply was enhanced (Figure $2 b)$. Such increase in nutrient concentration in leaves was also observed for canarygrass (Phalaris arundinaceae) by Cherney et al. (2004) and for ryegrass (Lolium perenne cv. Tivoli) by Gislum et al. (2003).

With the nitrogen supply at $14 \mathrm{mg} \mathrm{L}^{-1}$ (much lower than the $210 \mathrm{mg} \mathrm{L}^{-1}$ recommend in the Sarruge's nutrient solution), nitrogen concentrations in the sampled leaf tissues (EL, NL and ML) at the two harvests ranged from 9 to $17 \mathrm{~g} \mathrm{~kg}^{-1}$. In such situations Marandu grass had short size, with short length and yellowish leaf lamina. According to Werner (1986), these symptoms indicate nitrogen deficiency in forage grasses.

The two newly expanded leaf lamina have been suggested to be sampled for nutritional diagnosis in forage grasses, and the critical level for nitrogen has been determined within the range of 14.4 to $22.0 \mathrm{~g}$ $\mathrm{kg}^{-1}$ (Santos, 1997; Colozza, 1998; Manarin, 2000; Monteiro, 2004). Depending on the rate of nitrogen in the nutrient solution, this shoot part revealed the nitrogen status (deficiency or adequate nutrition) for Marandu grass, confirming that it is very useful for diagnosis purposes.

\section{Sulphur in leaf tissues}

The nitrogen $\mathrm{x}$ sulphur interaction was significant for sulphur concentration in the newly expanded leaf lamina collected at the first harvest (Figure 3) and in three types of leaf tissues sampled at the second harvest (Figure 4) of Marandu grass.

Newly expanded leaf lamina sampled at both harvests (Figures 3 and 4b) had the lowest sulphur concentrations when Marandu grass was supplied with low sulphur (about $3.2 \mathrm{mg} \mathrm{L}^{-1}$ ) rates in the nutrient solution, mainly at the high nitrogen rates (about 462 $\mathrm{mg} \mathrm{L}^{-1}$ during the first growth period and above 126 $\mathrm{mg} \mathrm{L}^{-1}$ during the second). Otherwise, the highest leaf

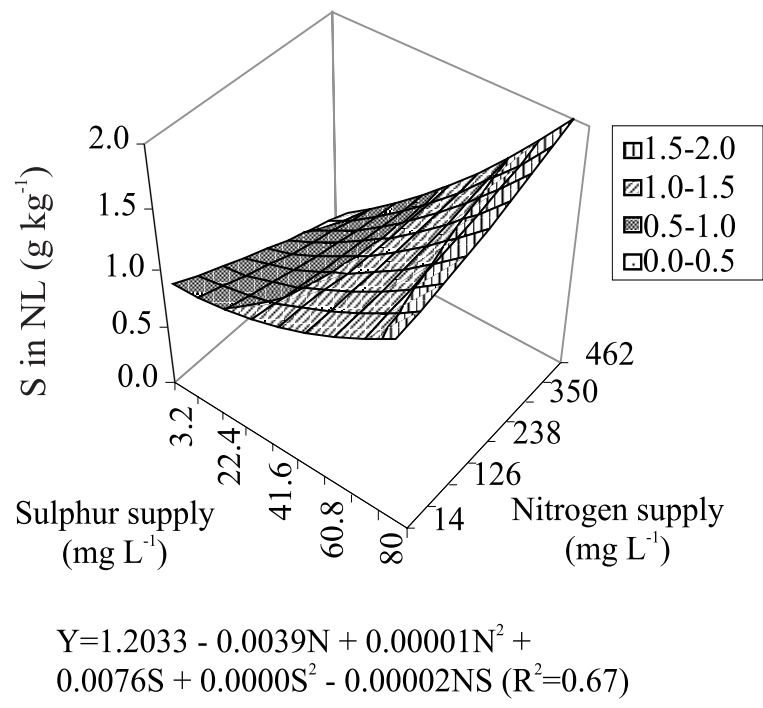

Figure 3 - Sulphur concentration in the newly expanded leaf lamina (NL) at the first harvest of Marandu grass, as related to the nitrogen and sulphur rates combinations.

lamina (any one of them) sulphur concentrations (near or above $2 \mathrm{~g} \mathrm{~kg}^{-1}$ ) were found in plants supplied with high rates of sulphur (about $80 \mathrm{mg} \mathrm{L}^{-1}$ ), even in nutrient solution with high nitrogen rates. As these newly expanded leaf lamina had similar variations in sulphur concentrations at both sampling times and also well reproduced the changes in the supply of this nutrient to roots, even in a wide range of nitrogen rates, this shoot part can be confirmed as the recommended plant tissue for sulphur nutrition diagnosis in Marandu grass.

Sulphur concentration in the emergent leaves of Marandu grass at the second harvest (Figure 4a) was very low (lower than $1 \mathrm{~g} \mathrm{~kg}^{-1}$ ) in a condition of very low sulphur supply, at any nitrogen rate in the nutrient solution. Plants receiving high nitrogen and sulphur rates had emergent leaves with high sulphur concentrations (greater than $2 \mathrm{~g} \mathrm{~kg}^{-1}$ ).

Unlike the emergent leaves and newly expanded leaf lamina, mature leaf lamina had sulphur concentration with higher sensitivity to nitrogen than to sulphur in the nutrient solution (Figure 4c). Sulphur concentrations in mature leaf lamina ranged from 0.32 to $2.30 \mathrm{~g} \mathrm{~kg}^{-1}$, but they did not express sulphur supply to the roots of this forage. This finding is not in agreement with one of the basic assumptions for the use of this leaf tissue for diagnostic purposes, and it cannot be recommended for sulphur nutritional diagnosis of Marandu grass (Malavolta et al., 1997).

\section{$\mathrm{N}: \mathrm{S}$ ratio in leaf tissues}

The interaction between nitrogen and sulphur rates for the Marandu grass was significant for the $\mathrm{N}: \mathrm{S}$ ratio in emergent leaves and mature leaf lamina col- 

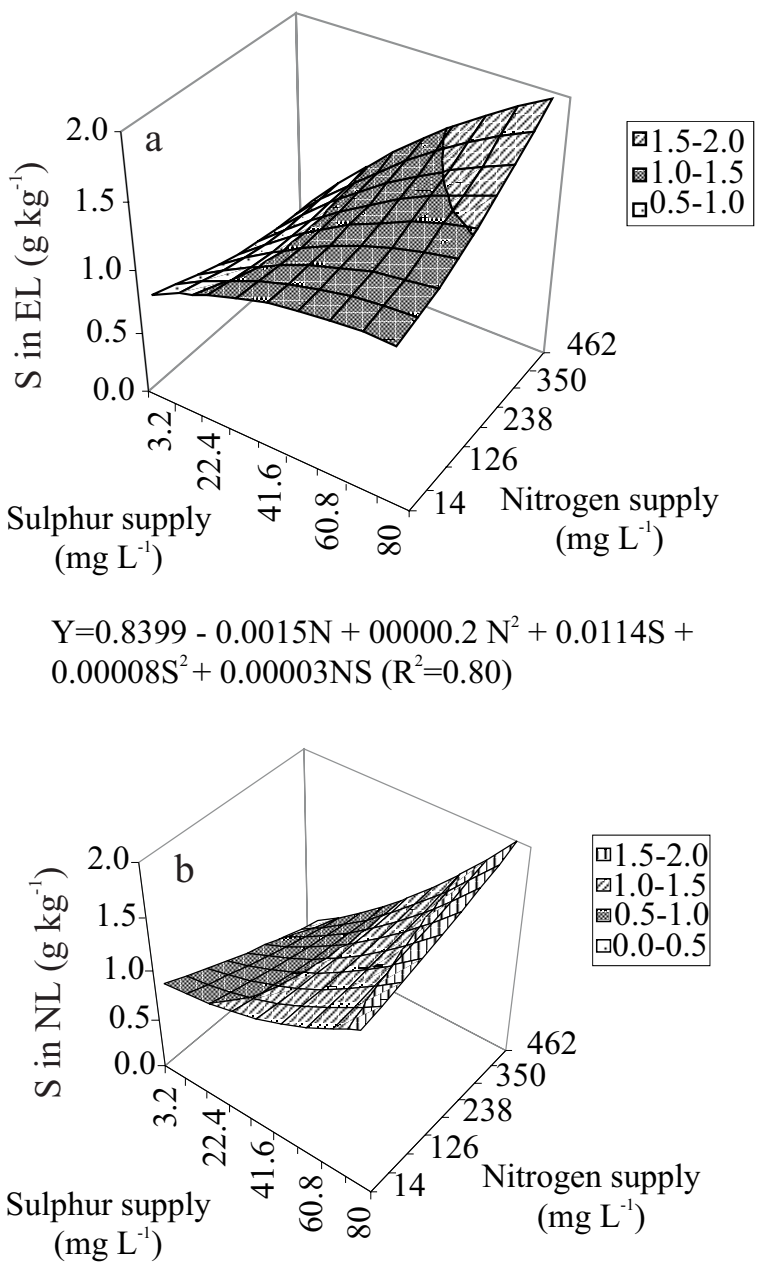

$\mathrm{Y}=0.9679-0.0017 \mathrm{~N}+0.000006 \mathrm{~N}^{2}+0.00005 \mathrm{~S}+$ $0.00009 \mathrm{~S}^{2}+0.00003 \mathrm{NS}\left(\mathrm{R}^{2}=0.65\right)$

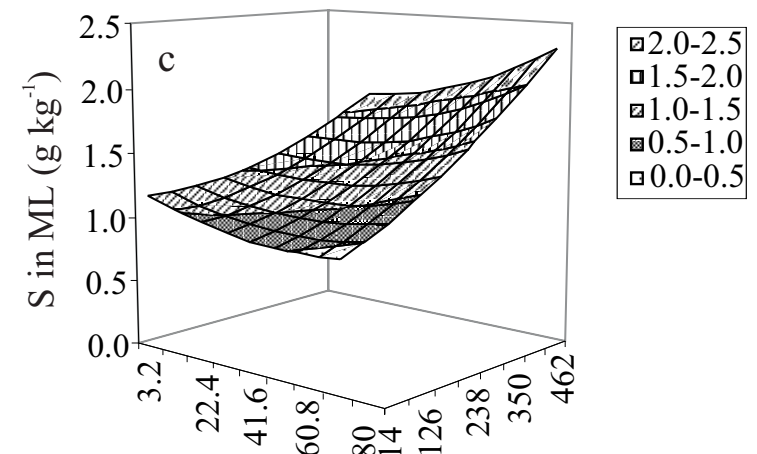
Sulphur supply Nitrogen supply $\left(\mathrm{mg} \mathrm{L}^{-1}\right) \quad\left(\mathrm{mg} \mathrm{L}^{-1}\right)$

$$
\begin{aligned}
& \mathrm{Y}=1.2147-0.0030 \mathrm{~N}+0.000002 \mathrm{~N}^{2}+0.0045 \mathrm{~S}+ \\
& 0.00009 \mathrm{~S}^{2}+0.00003 \mathrm{NS}\left(\mathrm{R}^{2}=0.60\right)
\end{aligned}
$$

Figure 4 - (a) Sulphur concentration in emergent leaves (EL), (b) in newly expanded leaf lamina (NL), and (c) in mature leaf lamina (ML) (c) collected at the first harvest of Marandu grass, as related to the nitrogen and sulphur rates combinations. lected at both harvests, and also in newly expanded leaf lamina sampled at the end of the second growth of this forage (Figures 5 and 6). The use of nutrient concentration ratios has been proposed to enhance the precision of tissue assays by minimizing the effects of the kind of the sampled plant part, tissue age, growth rate and other factors (Duke \& Reisenauer, 1986).

Werner \& Monteiro (1988) revised a series of studies on the N:S ratio for forages, and pointed out that this ratio usually ranges from $12: 1$ to $17: 1$ in well supplied grasses with both nitrogen and sulphur. The results reported in the present study for three types of leaf tissues collected from Marandu grass demonstrated a much larger range, with values ranging from 5 to 35 in the young leaf tissues (Figures 5a, 6a, and

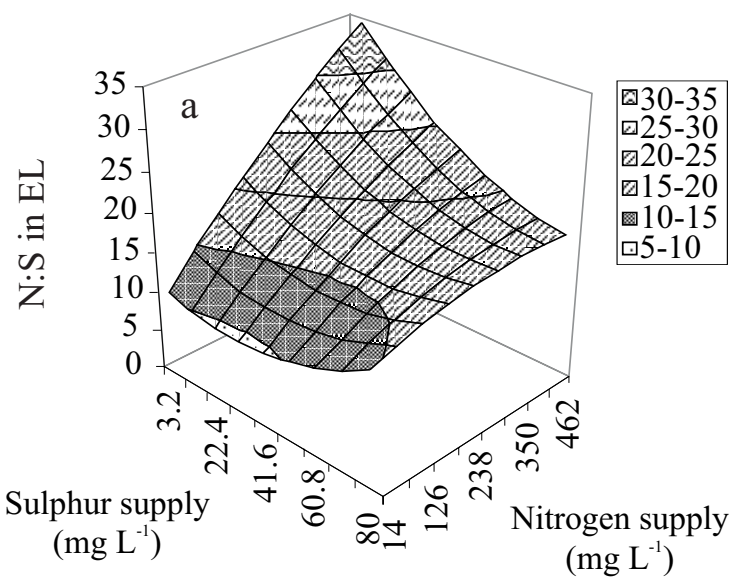

$\mathrm{Y}=10.1810+0.0693 \mathrm{~N}-0.00003 \mathrm{~N}^{2}-0.1181 \mathrm{~S}+$ $0.0021 \mathrm{~S}^{2}-0.0006 \mathrm{NS}\left(\mathrm{R}^{2}=0.45\right)$

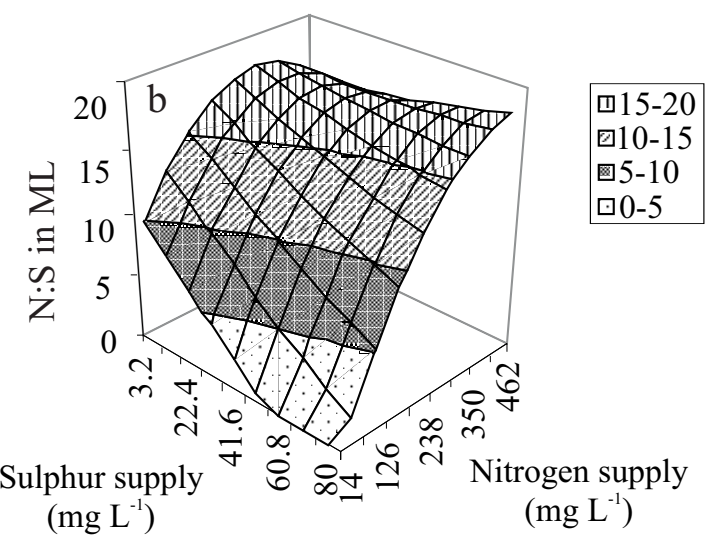

$$
\begin{aligned}
& \mathrm{Y}=9.7538+0.0608 \mathrm{~N}-0.000105 \mathrm{~N}^{2}-0.2121 \mathrm{~S}+ \\
& 0.00026 \mathrm{~S}^{2}+0.0004 \mathrm{NS}\left(\mathrm{R}^{2}=0.60\right)
\end{aligned}
$$

Figure 5 - (a) N:S ratio in emergent leaves (EL), and (b) in mature leaf lamina (ML) collected at the first harvest of Marandu grass, as related to the nitrogen and sulphur rates combinations. 


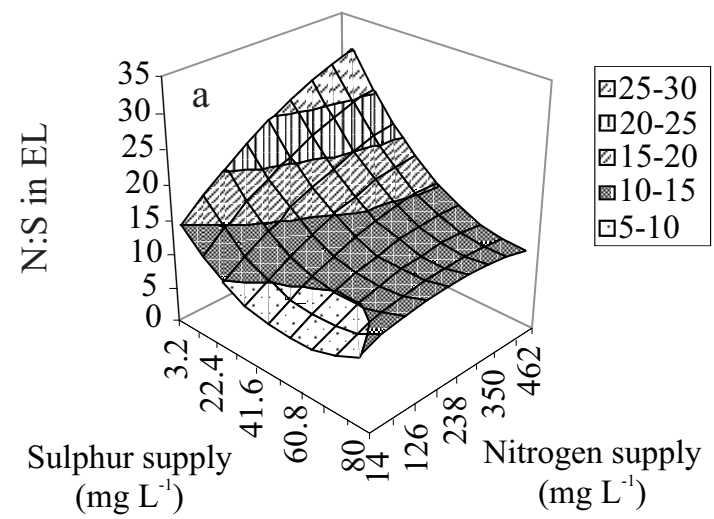

$\mathrm{Y}=15.4781+0.0540 \mathrm{~N}+0.00004 \mathrm{~N}^{2}-$ $0.3634 \mathrm{~S}+0.0036 \mathrm{~S}^{2}-0.0004 \mathrm{NS}\left(\mathrm{R}^{2}=0.73\right)$

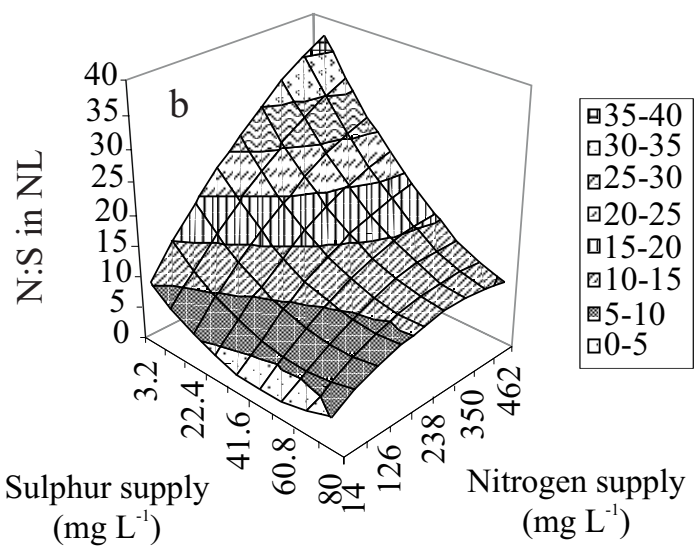

$\mathrm{Y}=10.0633+0.0906 \mathrm{~N}-0.00006 \mathrm{~N}^{2}-0.3164 \mathrm{~S}+$ $0.0031 \mathrm{~S}^{2}-0.0006 \mathrm{NS}\left(\mathrm{R}^{2}=0.77\right)$

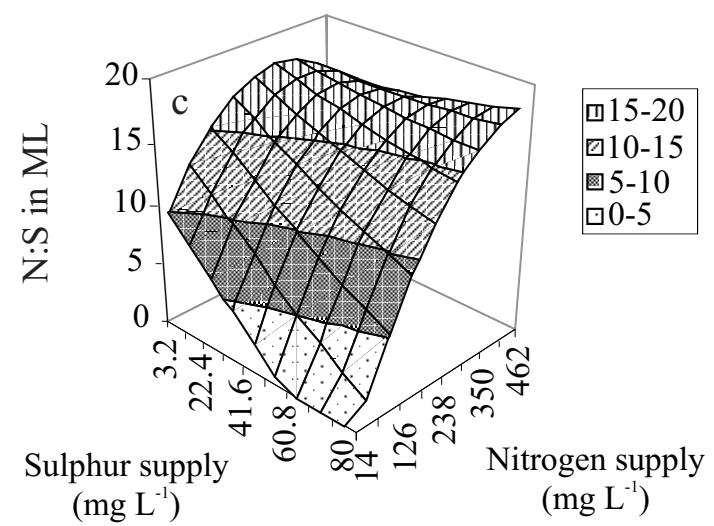

$\mathrm{Y}=6.1369+0.0413 \mathrm{~N}-0.000004 \mathrm{~N}^{2}-0.1009 \mathrm{~S}-$ $0.0007 \mathrm{~S}^{2}+0.0004 \mathrm{NS}\left(\mathrm{R}^{2}=0.82\right)$

Figure 6 - (a) N:S ratio in emergent leaves (EL), (b) in newly expanded leaf lamina (NL), and (c) in mature leaf lamina (ML) collected at the second harvest of Marandu grass, as related to the nitrogen and sulphur rates combinations.
$6 \mathrm{~b})$ and reached 20 in the mature leaf lamina (Figures $5 \mathrm{~b}$ and $6 \mathrm{c}$ ). This lower N:S ratio in mature tissues can be explained by the high nitrogen mobility from older to younger tissues while such mobility does not occur with sulphur (Marschner, 1995; Mengel \& Kirkby, 2001).

The highest variation in the $\mathrm{N}: \mathrm{S}$ ratio (from 2.8:1 to $37.2: 1$ ) was obtained in the newly expanded leaf lamina. Again, this confirms the high sensitivity of this leaf tissue in reflecting changes in sulphur supply to roots, and recommendation to use this shoot part for nutritional diagnosis. Also, Santos (1997) and Monteiro et al. (2004b) reported similar findings for Brachiaria decumbens and Panicum maximum cv. Tanzânia.

Very low N:S ratios (lower than 5) were found in the sampled leaf tissues when nitrogen was supplied at low rates (about $14 \mathrm{mg} \mathrm{L}^{-1}$ ) in combination with intermediate or high sulphur rates (from 40 to $80 \mathrm{mg} \mathrm{L}^{-1}$ ). Such low ratios result from sulphur excess in relation to nitrogen (Dijkshoorn \& van Wijk, 1967; Werner \& Monteiro, 1988). This is in agreement with the suggestion of Monteiro et al. (2004b) that sulphur fertilization of pasture grasses should be recommended when these forages are well fertilized with nitrogen. Stevens (1985) emphasized that both nitrogen and sulphur supply are directly related and they must be in plant tissues in adequate proportions and amounts for the optimal synthesis of protein. In the search on the effects of sulphur supply on nitrogen absorption and assimilation by ryegrass, Millard et al. (1985) reported changes in the N:S ratio due to increased plant tissue nitrogen concentrations and reduced plant sulphur concentrations.

The highest N:S ratios for Marandu grass leaf tissues arise from both the low sulphur (about $3.2 \mathrm{mg} \mathrm{L}^{-1}$ ) and high nitrogen (about $462 \mathrm{mg} \mathrm{L}^{-1}$ ) rates (Figures 5 and 6). This was clearly related to sulphur deficiency in the grass (Dijkshoorn \& van Wijk, 1967; Werner \& Monteiro, 1988). It is worthwhile to emphasize the ability of younger tissues in exhibiting higher $\mathrm{N}: \mathrm{S}$ ratios than mature leaves, which makes it easy to identify sulphur deficiency when such tissues are sampled. Emergent leaves and newly expanded leaf lamina were observed to be appropriated for the identification of sulphur nutritional disorders and the newly expanded leaves were superior to the emergent ones, since they had wider N:S ratios. Therefore, newly expanded leaf lamina is suggested as the best plant tissue for sulphur nutrition diagnosis in Marandu grass. This is in agreement with Mattos (1997), Santos (1997), Manarin (2000), Pereira (2001) and Monteiro et al. (2004a) for forage grasses. 


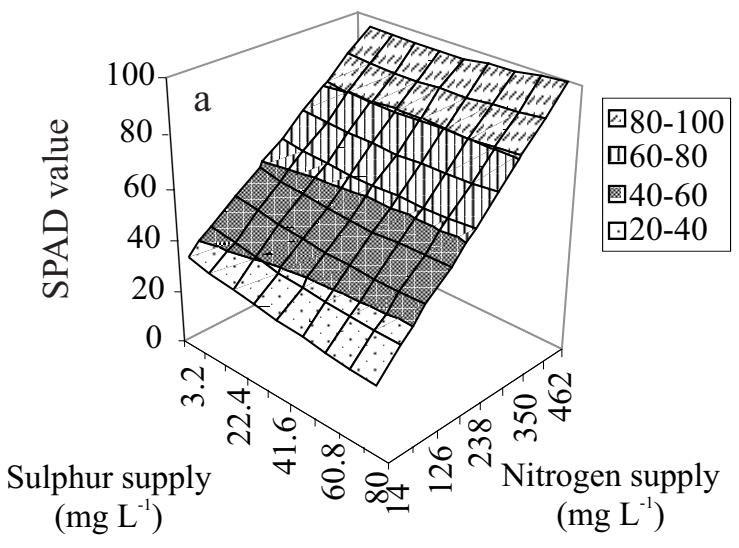

$\mathrm{Y}=35.4373+0.1307 \mathrm{~N}-0.0002 \mathrm{~N}^{2}-0.2341 \mathrm{~S}-$ $0.0012 \mathrm{~S}^{2}+0.0004 \mathrm{NS}\left(\mathrm{R}^{2}=0.85\right)$

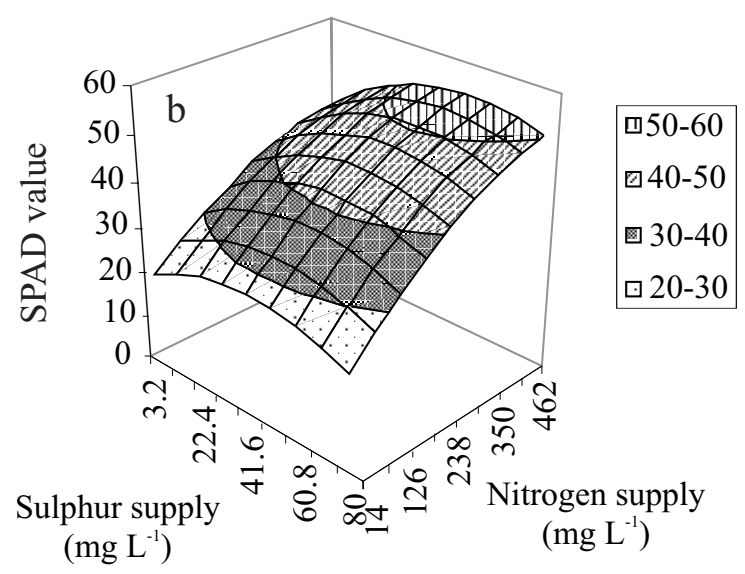

$\mathrm{Y}=18.1351+0.0959 \mathrm{~N}-\mathrm{N} 0.0001 \mathrm{~N}^{2}+0.3669 \mathrm{~S}-$ $0.0043 \mathrm{~S}^{2}+0.0002 \mathrm{NS}\left(\mathrm{R}^{2}=0.89\right)$

Figure 7 - SPAD value in newly expanded leaf lamina (NL) collected at the first (a) and at the second (b) harvest of Marandu grass, as related to the nitrogen and sulphur rates combinations.

These results emphasize the importance of using the diagnostic leaf for analyses of plant tissues. Pasricha \& Fox (1993) pointed out that although N:S ratios have been used successfully to diagnose sulphur needs over a wide range of $\mathrm{S}$ nutrition, considerable fluctuations in this ratio have been reported as sulphur levels in plants approach adequacy and that one of the problems of using $\mathrm{N}: \mathrm{S}$ ratios is that $\mathrm{S}$ is a relatively immobile nutrient in plants. When new plant tissues were sampled and analyzed, these problems with the $\mathrm{N}: \mathrm{S}$ ratio were overcome.

\section{SPAD}

The interaction between nitrogen and sulphur rates was significant for the chlorophyll SPAD values determined on the newly expanded leaf lamina at the two harvests of Marandu grass (Figure 7). Mattos (2001) also reported the significance for such interaction when the SPAD values were measured for Brachiaria decumbens.

At the first growth period of Marandu grass, the SPAD values were mainly affected by nitrogen rates when combined with high sulphur rates (Figure $7 \mathrm{a}$ ). However, during the second growth of the grass, SPAD values were highly influenced by nitrogen and sulphur supply, at any rate of both (Figure 7b). At this growth rate and with high nitrogen supply (higher than $350 \mathrm{mg} \mathrm{L}^{-1}$ ), high SPAD readings were found only for intermediate or high sulphur rates (at least $40 \mathrm{mg} \mathrm{L}^{-1}$ ).

The relevance of SPAD for nutritional diagnosis purposes (mainly for nitrogen) in forage grasses is well described elsewhere (Santos, 1997; Manarin, 2000). The finding of this effect of sulphur together with nitrogen supply for this parameter suggests caution in the use of SPAD as the only tool for determining the nitrogen status of forage grasses. This concern was also raised by Hermann \& Taube (2005); when discussing the possibility of luxury nitrogen consumption by plants without detection through the chlorophyll meter. This would require sulphur status monitoring in the plants for an effective SPAD use for diagnostic purposes.

\section{CONCLUSIONS}

- Nitrogen concentration in emergent leaves, newly expanded leaves lamina and mature leaves is directly related to the nitrogen supply;

- Sulphur concentration, N:S ratio and SPAD in leaf tissues depended on both sulphur and nitrogen supplies;

- Mature leaf lamina nutrient concentrations and SPAD do not accurately indicate sulphur supply;

- Newly expanded leaf laminas are adequate indicators of the nitrogen and sulphur supplies.

\section{ACKNOWLEDGEMENT}

To FAPESP and CNPq for financial support and fellowships.

\section{REFERENCES}

CHERNEY, J.H.; KETTERINGS, Q.M.; ORLOSKI, J.L. Plant and soil elemental status as influenced by multi-year nitrogen and potassium fertilization. Journal of Plant Nutrition, v.27, p.991-1014, 2004

COLOZZA, M.T. Rendimento e diagnose foliar dos capins Aruana e Mombaça cultivados em Latossolo Vermelho-Amarelo adubado com doses de nitrogênio. Piracicaba: USP/ESALQ, 1998. 127p. (Tese - Doutorado).

DIJKSHOORN, W.; LAMPE, J.E.M. A method of diagnosing the sulphur nutrition status of herbage. Plant and Soil, v.13, p.227$241,1960$. 
DIJKSHOORN, W.; van WIJK, A.L. The sulphur requirements of plants as evidence by the sulphur-nitrogen ratio in the organic matter. Plant and Soil, v.26, p.129-157, 1967.

DUKE, S.H.; REISENAUER, H.M. Roles and requirements of sulfur in plant nutrition. In: TABATABAI, M.A. (Ed.). Sulfur in agriculture. Madison: ASA; CSSA; SSSA, 1986. p.123-168.

DWYER, L.M.; TOLLENAAR, M.; HOUWING, L. A nondestructive method to monitor leaf greenness in corn. Canadian Journal of Plant Science, v.71, p.505-509, 1991.

GISLUM, R.; WOLLENWEBER, B.; BOELT, B.; JENSEN, E.S. Uptake and distribution of nitrogen in perennial ryegrass: effect of additional applications at vegetative growth. Journal of Plant Nutrition, v.26, p.2375-2389, 2003.

HERMANN, A.; TAUBE, F. Nitrogen concentration at maturity an indicator of nitrogen status in forage maize. Agronomy Journal, v.97, p.201-210, 2005

HITSUDA, K.; YAMADA, M.; KLEPLER, D. Sulphur requirement of eight crops at early of growth. Agronomy Journal, v.97, p.155-159, 2005.

JONES, M.B. Yield, percent nitrogen, and total nitrogen uptake of various California annual grassland species. Agronomy Journal, v.55, p.254-257, 1963

LITTELL, R.C.; MOTT, G.O. Computer assisted design and analysis of response surface experiments in agronomy. Soil and Crop Society of Florida Proceedings, v.34, p.94-97, 1975.

MALAVOLTA, E.; VITTI, G.C.; OLIVEIRA, S.A. Avaliação do estado nutricional de plantas: princípios e aplicações. Piracicaba: POTAFOS, 1997. 319p.

MANARIN, C.A. Respostas fisiológicas, bioquímicas e produtivas do capim-Mombaça a doses de nitrogênio. Piracicaba: USP/ ESALQ, 2000. 58p. (Dissertação - Mestrado).

MARSCHNER, H. Mineral nutrition of higher plants. New York: Academic Press, 1995. 889p.

MATTOS, W.T. Diagnose nutricional de potássio em duas espécies de braquiária. Piracicaba: USP/ESALQ, 1997. 74p. (Dissertação - Mestrado).

MATTOS, W.T. Avaliação de pastagem de capim-braquiária em degradação e sua recuperação com suprimento de nitrogênio e enxofre. Piracicaba. USP/ESALQ, 2001. 97p. (Tese Doutorado)

MEIRELLES, N.M.F.; WERNER, J.C.; ABRAMIDES, P.L.G.; CARRIEL, J.M.; PAULINO, V.T.; COLOZZA, M.T. Nível crítico de fósforo em capim-colonião cultivado em dois tipos de solo; Latossolo Vermelho-Escuro e Podzólico VermelhoAmarelo. Boletim de Indústria Animal, v.45, p.215-232, 1988.

MENGEL, K.; KIRKBY, E.A. Principles of plant nutrition. Dordrecht: Kluwer Academic Publishers, 2001. 849p.

MILLARD, P.; SAHARP, G.S; SCOTT, N.M. The effect of sulphur deficiency on the uptake and incorporation of nitrogen in ryegrass. Journal of Agricultural Science, v.105, p.501504, 1985.

MINOLTA CAMERA CORPORATION. Manual for chlorophyll meter SPAD-502. Osaka, 1989. 22p.
MONTEIRO, F.A. Concentração e distribuição de nutrientes em gramíneas e leguminosas forrageiras. In: SIMPÓSIO SOBRE MANEJO ESTRATÉGICO DAS PASTAGEM, 2., Viçosa, 2004. Anais. Viçosa: DZO,UFV, 2004. p.71-107.

MONTEIRO, F.A.; COLOZZA, M.T.; WERNER, J.C. Enxofre e micronutrientes em pastagens. In: SIMPÓSIO SOBRE MANEJO DA PAStAGEM, 21., Piracicaba, 2004. Anais. Piracicaba: FEALQ, 2004a. p.279-301.

MONTEIRO, F.A.; VENDEMIATTI, J.A.; SILVEIRA, C.P. Concentração de enxofre e relação $\mathrm{N}: \mathrm{S}$ em folhas diagnósticas de capim-Tanzânia suprido com doses de nitrogênio e enxofre. In: REUNIÃO ANUAL DA SOCIEDADE BRASILEIRA DE ZOOTECNIA, Campo Grande, 2004. Campo Grande: SBZ, 2004b. 1 CD-ROM

NIELSEN, D.; HOGUE, E.J.; NIELSEN, G.H.; PARCHOMCHUK, P. Using SPAD-502 values to assess the nitrogen status of apple trees. HortScience, v.30, p.508-512, 1995.

PASRICHA, N.S.; FOX, R.L. Plant Nutrition sulfur in the tropics and subtropics. Advances in Agronomy, v.50, p.209-269, 1993.

PEREIRA, W.L.M. Doses de potássio e de magnésio em solução nutritiva para capim-Mombaça. Piracicaba: USP/ESALQ, 2001. 124p. (Tese - Doutorado).

SANTOS, A.R. Diagnose nutricional e respostas do capimBraquiária submetido a doses de nitrogênio e enxofre. Piracicaba: USP/ESALQ, 1997. 115p. (Tese - Doutorado).

SARRUGE, J.R. Soluções nutritivas. Summa Phytopathologica, V.1, p.231-233, 1975

SARRUGE, J.R.; HAAG, H.P. Análises químicas em plantas. Piracicaba: ESALQ, 1974. 54p.

SAS INSTITUTE. The SAS-system for windows: release 6.08 (software). Cary, 1996.

STEVENS, R.J. Evaluation of the sulphur status of some grasses for silage in Northern Ireland. Journal of Agricultural Science, v. 105, p. $581-585,1985$.

WERNER, J.C. Adubação de pastagens. Nova Odessa: Instituto de Zootecnia, 1986. 49p. (Boletim Técnico, 18).

WERNER, J.C.; HAAG, H.P. Estudos sobre a nutrição mineral de alguns capins tropicais. Boletim de Indústria Animal, v.29, p.191-245, 1972 .

WERNER, J.C.; MONTEIRO, F.A. Respostas das pastagens a aplicação de enxofre. In: SIMPÓSIO ENXOFRE E MICRONUTRIENTES NA AGRICULTURA BRASILEIRA, Londrina, 1988. Anais. Londrina: Embrapa, CNPS; IAPAR, 1988. p.87-102.

YAMAMOTO, A.; NAKAMURA, T.; ADU-GYAMFI, J.J. SAIGUSA, M. Relationship between chlorophyll content in leaves of sorghum and pigeonpea determined by extraction method and by chlorophyll meter (SPAD-502). Journal of Plant Nutrition, v.25, p.2295-2301, 2002.

Received February 24, 2006

Accepted November 29, 2006 